\title{
TENTH NATIONAL COUNCIL MEETING OF S.A.S.P.
}

\section{(Pretoria, September 1st, 2nd September, 1973)}

\section{Presidential Address}

\section{Prof. B. BROMILOW-DOWNING}

Namens die Suid-Afrikaanse Vereniging vir Fisioterapie moet ek die edelagbare Minister van Gesondheid hartlik bedank vir sy persoonlike teenwoordigheid op hierdie 10de Vergadering van die Nasionale Raad. Ons waardeer opreg dat hy. hom die tyd vergun het om as gas spreker op te tree en hierdie vergadering amptelik te open. Die teenwoordigheid van soveel verteenwoordigers van die verenigings van die ander aanvulende hulpdienste word ook hoog op prys gestel.

Die jaar 1973 is 'n baken in die geskiedenis van die pnvullende hulpdienste in die Republiek. In hierdie jaar net parelange harde werk van baie mense en baie verenigings vrugte begin afwerp. In hierdie jaar het ons die stigting van die beroepsrade vir drie van die aanvullende gesondheid dienste gesien, naamlik Fisioterapie, Optometrie en Mediese Tegnologie. Ek is persoonlik baie trots daarop dat, hoewel miskien terloops, die eerste Beroepsraad wat gestig is die van Fisioterapie is, en die eerste Beroepsraad wat 'n vergadering gehou het ook die van Fisioterapie is.

Dit is ook terloops dat ek vir die grootste gedeelte van my profesionele lewe verbonde is aan die aanvullende gesondheidsdienste. As superintendent van die Frere Hospitaal, Oos Londen, het ek 'n kursus in Radiografie gestig. Dit was die begin van my belangstelling. Later, as Dekaan van die Fakulteit Geneeskunde, Universiteit van Kaapstad, het ek Kursusse in Fisioterapie, Arbeidsterapie en nou Spraakterapie begin. Vir ongcveer tien jaar is ek nou die voorsitter van die Geneeskundige Raad se Komitee op Aanvullende Hulpdienste dit is dus vanselfsprekend waarom ek nou so innig bly is dat die paramediese dienste met sulke rasseskrede gedurende die laaste paar jaar gevorder het.

It is a matter of interest that the last Presidential Address I delivered on the occasion of the 9 th meeting of the National Council should have been on the very day that the Amendment to the Medical, Dental and Tharmacy Act, Act No. 43 of 1971 was promulgated In the Government Gazette and that I should have devoted my Presidential Address on that occasion to an explanation of the very amending Act which makes possible the compulsary registration of supplementary health personnel.

It is in terms of this Act that the professional boards are now being established. As I have said it is a matter of great pride to me that the first board so established was that of Physiotherapy. I think it is only just that this should have been the case. The South African Society of Physiotherapy has played a leading part in the evolution of the present situation. At the risk of repeating myself may I remind you that our Society in 1927 i.e. two years after its foundation, interviewed members of Parliament and the Minister of Health in an attempt to obtain registration for masseurs (as the term was then) under the South African Medical and Dental Council then under consideration and created by Parliament in 1928. They were successful and the first rules governing the conduct of masseurs was published in the July issue of the Government Gazette in 1930 i.e. two years after the passing of the Act. A year later 13 masseurs had placed themselves voluntarily on the register. It was not until 1946 i.e. 15 years later that other paramedicals registered with the Council. On the 31 st December 1972,1530 physiotherapists names appeared on the Council's register (this does not include the 198 masseurs so registered). The Medical 'Tech. nologists were next in number with 1103 names (all categories) on the register (with the establishment of the professional boards registrations have been more accurately determined). The principal of compulsory registration of physiotherapists (and other paramedicals) has been advocated by our Society since its inception.

The saga of compulsory registration is a story of a protracted struggle with abortive attempts at legislation in 1952 and 1955 when on each of two occasions a Bill for the compulsory registration of supplementary health personnel failed to reach the statute book. Act No. 43 of 1971 makes compulsory registration possible but a lot of work will still have to be undertaken before it is possible for areas to be prescribed where registration will be compulsory. The present situation is one of experimentation and cautious progress towards realising this ideal.

It is a bold measure adopted by our legislature to make it possible under certain conditions for each of the professions supplementary to Medicine to form its own professional board under the overall aegis of the South African Medical and Dental Council. It is interesting to note that in the recently published Bill to consolidate and amend the legal requirements of training and registration of medical practitioners, dentists supplementary health service personnel the principle of the holism of the professions providing health services is maintained and provision is made for the retention of the professional boards under the aegis of the Medical Council.

I have stressed the part played by the South African Society for Physiotherapy in achieving this goal. We here today should be greatly appreciative of the dedication and devotion to duty of members of the Society throughout the years. In 1973 a great university recognised the place of Physiotherapy by conferring on the head of the Department of Physiotherapy the highest academic title namely that of Professor. I refer to Miss Jean Blair.

The Society. can well be proud of its achievements. In terms of the Act the Minister has expressed his opinion that the South African Society of Physiotherapy is representative of the majority of persons whose name appears on the register and the Medical Council thus consulted with our Society before recommending to the State President that a professional board be established in respect of the profession of Physiotherapy.

The status enjoyed by the South African Society is indicative of the value placed upon such a Professional Society by the authorities concerned with the provision of health services in the Republic of South Africa. Membership of such societies in the case of the Supplementary Health Services is not obligatory. It is thus gratifying to know that the vast majority of practisıng and even non-practising physiotherapists are members of the South African Society. The Society is affiliated to the World Confederation of Physical Therapy and a strong South African delegation will be attending the next meeting of the World Confederation to be held in Montreal in June 1974. Papers will be presented illustrative of 
the work being done by paramedicals (in particular physiotherapists) in the provision of health services in the Republic of South Africa. Our legislature governing paramedicals is almost unique in that it provides a large measure of self-determination and autonomy to the paramedical groups but at the same time retaining the holistic approach to the patient. We have avoided the multiplicity of independent statutory boards and councils as in the case for instance in the United Kingdom where in addition to the General Medical Council they have the General Nursing Council, the General Midwifery Council, the General Optical Council and the Board to register professions supplementary to Medicine. Under our system each of the professions for whom a professional board is established remains under the aegis of the Medical and Dental Council which provides overall supervision to maintain uniformity of approach. Thus the concept of a Health team is virtually legally protected. No profession (be it medical or paramedical) engaged in providing health services can "go it alone". Each is dependent on the other. Whereas the medical practitioner by reason of his training is the captain of the team he is not himself in the position to provide the highly skilled services of persons specially trained in particular fields. It is his duty to co-ordinate the services to ensure that the public secures the benefits of modern medical science.

With the rapid development of the paramedical professions a problem has arisen as to how the medical professions of the skills, functions and limitations of these rapidly developing professions. The undergraduate medical curriculum is so loaded that my faculty board has long ago established the principle that nothing will be added to the curriculum unless a like amount is taken out. However, I am of the opinion that the Physiotherapy Departments are becoming less the dumping grounds of the diagnostically destitute and on fewer occasions are reference slips marked "For Physiotherapy, please", with no indication of the treatment. There is an increasing inclination of the medical practitioner to consult with the paramedicals as equal professional colleagues, the patient being regarded as a whole and not fragmented and divided between the various professions with varying professional interests. The interest of the patient must remain paramount and is best served by a medical team composed of the relevant skilled professional persons.

Professional societies have a two-fold function. The one is virtually that of a trade union to see that its members received due recognition from the employing authorities for their professional services and are adequately financially rewarded. The second and perhaps more important function in the public interest is that of the maintenance of professional standards. It is for the societies to campaign for the recognition of their professional status by other professions. It is for the societies to take the lead in establishing correct interprofessional relationships to ensure that their professions receive due and adequate recognition, it is for the societies to counteract the untrained, unorthodox practitioners who trade on the gullibility of the public. The recently published Bill goes much further in protecting the public from the quack than is at present the case. Legislation can go so far but has its limitations. The education of the public in this regard is of far greater importance than any legislation. This education can best be carried out through the medium of the professional societies. It is one of the professional societies' functions to educate the public and to demonstrate the
value of its services of properly trained persons.

I have endeavoured to show the vital role played by the societies in the establishment of proper control and in the protection of the public. Professional societies are very often criticised. People are apt to ask "what is the Society doing for me?" "What has the Society done about this and what has the Society done about that?" Such persons very often are not members of the Society or if they are members usually take very little active part in the work of the Society. To such persons my advice is join the Society if you are not a member, or if you are a member, take an active part and pull your weight rather than criticise the efforts of others.

Failure to join or resignation from professional societies makes no contribution either to the public interest or the status of the profession.

The National Council of our Society is now meeting for the 10th occasion. Mr. Minister, you may notice that I refer constantly to our Society. I should point out $t$ ( you as I have done to others on previous occasions that my office in this Society is that of President, you will notice Mr. Minister, that the word "Honorary" does not appear in my title thus as a working official of this Society I feel more than justified in referring to it as our Society.

The National Council of our Society will be meeting now for the 10th occasion. The Agenda is illustrative of the amount of work performed by the members of the Society throughout the country. We see on the Agenda reports from all parts of the country indicative of the professional activity that is being displayed on a nationwide basis. Although I am your President, I do not take an active part in the day to day running of the Society, therefore I feel that I am in a privileged position, although one of you I am not personally involved and thus I am able to comment on the work you have performed and are performing not only in the interests of your profession but to ensure that the public is safeguarded and is in receipt of a service of a very high standard. In particular I find the reports of Groups, Representatives and Branches of our Society most ininterests of the Society covering items from manipulative therapists to National Council for Aged, South. African Paraplegic Games Association. With no les than 10 branches of the Society throughout the country holding regular meetings at which not only the business of the Society is discussed but case presentations and clinical discussions take place, it can only result in continued professional interest and a high standard of service.

Although I hope to remain with you for the greater part of your meeting I would like to wish you every success and a very fruitful 10th Council meeting.

Ten slote wil ek u, Edelagbare Minister, bedank vir $\mathrm{u}$ teenwoordigheid hier vanoggend. Ek wil ook alle die Raadslede, wat van alle kante van die Republik vir hierdie 10de Vergadering van die Nasionale Raad gekom het baie hartlik welkom heet. U teenwoordigheid op hierdie dag en by hierdie vergardering word hoog op prys gestel. Ek hoop u sal die verrigtinge die moeile werd vind en dat $u$ terug huis toe sal gaan met die wete dat $u$ baie geleer het en nie $u$ tyd verspil het nie. Alle goeie wense vir 'n doeltreffende en gelukkige vergadering. 